\title{
FOREIGN INVESTORS - FRIENDS OR ENEMIES OF DOMESTIC ENTREPRENEURS?
}

\author{
Aleksandra Pavlović ${ }^{1}$ \\ Mladen Radišić ${ }^{2}$ \\ Andrea Ivanišević ${ }^{3}$
}

DOI: https://doi.org/10.31410/ERAZ.2019.135

\begin{abstract}
Besides the well-known factors that affect entrepreneurship: economic and technological development, culture and education, FDI should also be considered as an important factor for entrepreneurial development of a host country. Having that in mind, the aim of this paper is to analyze how FDI may affect the host country's entrepreneurial activity, through a literature review. In some of the analyzed papers foreign investors are seen as friends of the host country's entrepreneurship thanks to the capital inflows, know-how, managerial capacity and employment growth, but in some other papers are seen as enemies, owing to increasing import competition and discouraging domestic entrepreneurs. The main contribution of this paper is compressing into a single material an overview of the friendly and unfriendly based effects of FDI on the host country's entrepreneurship.
\end{abstract}

Keywords: Foreign direct investments, entrepreneurship, employment.

\section{INTRODUCTION}

Goreign direct investments (FDI) play an important role in a host country's economic development. FDI are very important especially for developing countries, because they contribute to economic growth and the growth of investment activities in the host country. The development that meets our own needs without compromising the ability of future generations to meet their own needs should be the main goal of any economy, especially the emerging ones. In international business research, assumption suggests that there is a positive relationship between FDI and the host country's entrepreneurship. But, if foreign investors want to find their place on the host country's market and be successful on it, it's very important to choose the right international market entry strategy (IMES). With a brief overview of the internationalization strategies and entrepreneurship, in this paper, emphasis is put on the two of IMES, which have the great importance for the domestic entrepreneurship -cross-border mergers and acquisitions (M\&A). Having that in mind, the aim of this paper is to analyze how FDI through IMES, especially M\&A, may affect the host country's entrepreneurship, through a literature review.

\section{POSITIVE AND NEGATIVE EFFECTS ON DOMESTIC ENTREPRENEURSHIP - A LITERATURE REVIEW}

A large number of scholars have been engaged in examining the impact of FDI on the host country's entrepreneurship. A large number of studies have shown the existence of positive as well as negative relation between FDI and domestic entrepreneurship, and the importance of IMES for the domestic entrepreneurship examination.

\footnotetext{
Faculty of technical sciences, University of Novi Sad, Trg Dositeja Obradovića 6, Serbia Faculty of technical sciences, University of Novi Sad, Trg Dositeja Obradovića 6, Serbia Faculty of technical sciences, University of Novi Sad, Trg Dositeja Obradovića 6, Serbia
} 
Foreign investors bring knowledge and modern technology that can spillover into the local economy, but they are also the source of increased competition in product and factor markets and may raise the opportunity cost of entrepreneurship compared to employment. The direction of the response of domestic entrepreneurship to FDI inflow relies on whichever of these two effects dominates. M\&A FDI inflows are negatively associated with domestic entrepreneurial activity, since there are negative FDI spillovers, especially through stronger competition and local wage structure, as well as entrepreneurial entry since there is negative horizontal spillover effect on domestic entrepreneurship in some industry clusters [1].

FDI have an important impact on the economic growth of the host country, especially their two types - vertical and horizontal FDI, which have a different impact on the accumulation of human capital and education. Vertical FDI are focused on increasing the efficiency of business and for such investors, countries with cheap workforce are attractive. These investors, in order to achieve the highest efficiency [2], offer low wages to workers, and the final result is demotivation of the host country's population for further training and education. On the other hand, horizontal FDI are market-oriented and such investors aim to support the market development of the host country, they are ready to offer higher salaries to the workers in exchange for their high expertise, resulting in a motivation of the population to improve through higher levels of education [3].

Entrepreneurship is an important determinant of FDI and countries, especially the emerging ones, should promote and encourage entrepreneurship, in order to attract FDI inflows. The success of entrepreneurs attracts resources such as venture capital and specialized labor. There is a need for sufficient human capital and high education level in host country [4]. Zhang-Markusen (ZM) theory starts from the assumption that there is an inverse (concave) connection between FDI and human capital, and the countries are grouped into income categories (low, middle and high level of income) [5]. Because of this, countries with low wages and human capital can't attract FDI. According to the ZM theory, the availability of skilled labor in the host country represents a foreign investor's direct request [6]. This means that foreign investor won't invest, even if the wages of unskilled labor in the host country are very low, if there is insufficient amount of human capital. Figure 1 shows the inverse U-shape relationship between SDI and human capital.

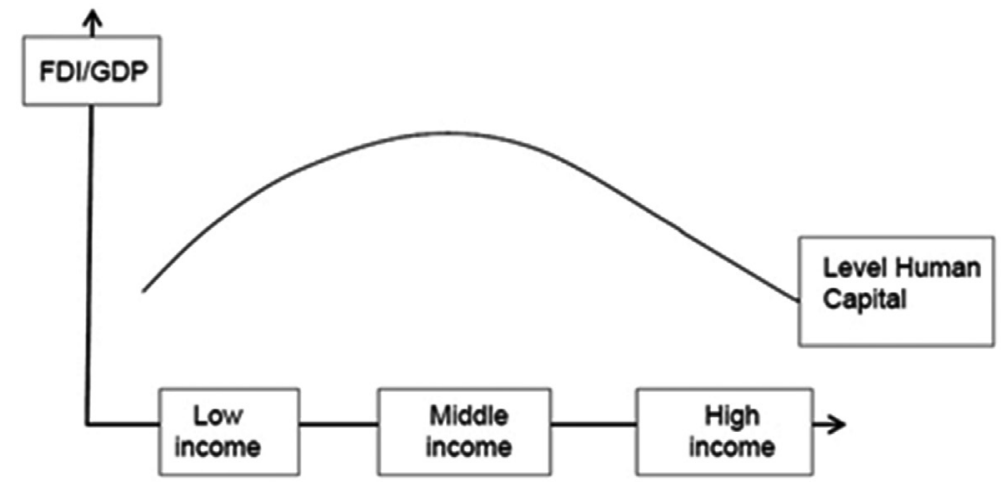

Figure 1: Inverse U-shape relationship between FDI and human capital [7]

Foreign investor will invest when a host country can offer a certain level of qualified workforce. Foreign investors are becoming more and more aware of the importance of skills, knowledge and expertise for their production. That's why they are looking for a workforce that has knowledge in the fields of engineering, information technology, organizational skills and business ad- 
ministration. FDI level was significantly higher in countries with higher education levels. This U-bond is stronger in the case of middle-income countries and weaker in low and high-income countries, as low-income countries are less competitive in the FDI market due to low wages and unskilled labor [7].

Regarding to FDI and domestic entrepreneurship, it's crucial to take the education level into account, since this determines the relationship between FDI and entrepreneurship is positive or negative and how strong that relationship is. In highly educated countries with increasing FDI levels, domestic entrepreneurs should take into account that they may expect serious competition from foreign investor firms to hire qualified employees. There is a positive spillover effects of inward FDI on entrepreneurship, but a strong negative association between education and entrepreneurship, suggesting that in countries with higher educated populations the number of entrepreneurs is lower but average firm size is higher [8].

Entrepreneurship as the creation of new ventures acts as a spillover mechanism through which the knowledge not exploited by essential organisations can be transferred to the market. Export-oriented entrepreneurship is a specific type of opportunity driven entrepreneurship that positively affects economic growth. The additional economic impact of any firm involved in export activity may occur because exporting is associated with learning processes that lead to improved productivity at the firm level [9].

The effect of FDI may be analyzed through a specific entry mode, on the host country's economic development. The impact of FDI on host country's economic growth and entrepreneurial activity differs by the country of origin of FDI and also differs depending on host country characteristics related to the "absorptive capacity" of a host country (the ability to reap the potential benefits of FDI), and host country characteristics, including the quality of institutions, the extent of trade openness and the stock of human capital [10].

The impact of FDI on entrepreneurial activity, with a focus on gender differences, is very important question for host country's economy. Research on this issue is significant, because it's still not clear in scientific literature whether FDI have an impact on domestic entrepreneurship, and is that effect positive or negative. The scientific research has shown that the impact of foreign direct investment on entrepreneurship is positive when spillovers into the host country are positive (in the form of new technologies, knowledge, etc.), and negative when foreign investors push local entrepreneurs from the market, who are discouraged and motivated to search for new opportunities on foreign markets. The impact of FDI on host country's entrepreneurship will vary depending on gender. The effect will be positive for male entrepreneurship, but negative for female entrepreneurship. Also, the higher level of taxes, primarily the taxation of enterprises, has a negative impact on entrepreneurship [11].

\section{FDI AND FIRM CREATION - CONCEPT FRAMEWORK}

Countries accept FDI as a source of capital and innovation, with aims of promotion competition and economic efficiency. Companies spread national borders worldwide in search of new markets and creative partnerships. Consumers are offered better quality, wider choices and lower prices of goods and services which they buy. FDI are targeted at those fast-growing sectors, serving as a successful example in the local economy and through large-scale training programs, have a role in reducing the restraining limits necessary changes. Competition on com- 
modities markets and production factors can reduce profits local firms, but the associated effects on industries that TNK suppliers can affect the reduction in input costs and increase profits. Local industrial sectors can grow up to the limits when local production takes over and expels enterprises established FDI funds.

Scientific results show that FDI significantly crowds-in new domestic firms when business startup regulations are lower. The connection between FDI and entrepreneurial activity of new host country's firms significantly depends on the existing regulatory environment for business startups. FDI significantly crowds-in new host country's firms when business start-up regulations are lower, and excessive start-up regulations usually are inefficient, thus dissuade new firm creation by increasing the costs of doing business and impeding the crowding-in effect of FDI in domestic product and labor markets, as well as in foreign markets. From a policy standpoint, reforms to establish the level of regulation that is most beneficial for the successful entry of new local firms can therefore play a critical role in enhancing the complementarity between foreign and domestic enterprises [12].

Taking into consideration industrial and geographical linkages of FDI spillovers in addition to competition effects of FDI [13]:

1. FDI spillovers are related to the labor market pooling, input sharing, and knowledge spillovers between industries;

2. Geographical linkages of FDI spillovers refer to localization theory of knowledge spillovers, which indicate that a successful commercialization process of new and entrepreneurial ideas possesses highly localized characteristics in geographical proximity;

3. Competition effects of FDI indicate an entry barrier for indigenous entrepreneurs to launch new businesses due to increased market competition caused by the presence of FDI firms in the host market.

Foreign ownership can help in restructure and enhance the productivity of host country's firms. The scientific research has shown that FDI has positive influence in reinforcing the creation of new firms, and, in line with the established literature, a foreign investment is likely to influence the job seeker to get employed rather to start their own business [14]. The results confirmed that the impact of foreign investment is, in general, positive and tends to influence the restructuring process of domestic enterprises.

Results showed that the inwards FDI positively influence the opportunity-driven entrepreneurs while the outwards FDI have a positive influence on the necessity-driven entrepreneurs. There is also a negative impact on the other category of entrepreneurs. FDI impact on the opportunity-driven entrepreneurs are strongly robust and opportunity entrepreneurship is associated with developed, innovation-driven economies, while the necessity entrepreneurship is important for the European efficiency-driven economies [15].

\section{SUMMARY}

FDI are an essential element of the host country's economic development and entrepreneurship. This paper presented a literature review on the influence of FDI on the host country's entrepreneurial activity, seeking to characterize the state of art on the theme, the reasons for using a certain investment strategy of internationalization by foreign investors, the friend or foe effects of FDI on the host country's entrepreneurship, sustainability, education and labor market. 
According to practice and academic content, FDI have both positive and negative effects on the host country's entrepreneurial activity.

The final effect also depends on IMES choice. In line with the majority of theoretical scientific papers that speak of the positive impact of greenfield investments, comparing to M\&As whose positive impact varies and can often be also negative, the country's economic policy makers should encourage FDI that are realized in the form greenfield investment, as they significantly contribute to the growth of productivity of the firms, the creation of new jobs and thus the reduction of unemployment, and are responsible for the economic growth of the country. This is especially important for underdeveloped and developing countries, as there is occasionally a negative correlation between cross-border M\&As and economic growth of the country.

The presented literature review of the FDI's impact on the host country's entrepreneurial activity shows that FDI have a lot of friendly impacts on the economic, entrepreneurial and social components of the host country's economy, but also that effects can be negative or unfriendly.

The proposal for future researches is to analyze both positive and negative effects of FDI on host country's entrepreneurship, especially through the IMES choice.

\section{REFERENCES}

[1] Danakol, S. H., Estrin, S., Reynolds, P., \& Weitzel, U. (2017). Foreign direct investment via $M \& A$ and domestic entrepreneurship: blessing or curse? Small Business Economics, Volume 48, Issue 3, pp 599-612.

[2] Strat, V. A. (2015). The relationship between the education system and the inflows of FDI for the Central and East European EU new member states. Romanian Journal of Economics, Institute of National Economy, Vol. 41, 76-92.

[3] Beugelsdijk, S., Smeets, R., \& Zwinkels, R. (2008). The impact of horizontal and vertical FDI on host's country economic growth. International Business Review, Vol. 17, 452-472.

[4] Fahed, W. (2013). The Effect of Entrepreneurship on Foreign Direct Investment. International Journal of Economics and Management Engineering, Vol:7, No:6.

[5] Zhang, K. H., \& Markusen, J. R. (1999). Vertical multinationals and host-country characteristics. Journal of Development Economics, Vol. 59, 233-252.

[6] Dorożyńska, A., \& Dorożyński, T. (2014). The role of human capital in attracting FDI the case of the Lodz region. Studia Prawno-Ekonomiczne, XCII (92), 221-241.

[7] Akin, M. S., \& Vlad, V. (2011). The Relationship between Education and Foreign Direct Investment: Testing the Inverse U Shape. European Journal of Economic and Political Studies, ejeps-4 (1).

[8] Berrill, J., O'Hagan-Luff, M., \& van Stel, A. (2018). The moderating role of education in the relationship between FDI and entrepreneurial activity. Small Business Economics, pp 1-19.

[9] González-Pernía, J.L., \& Peña-Legazkue, I. (2015). Export-oriented entrepreneurship and regional economic growth. Small Business Economics, Volume 45, Issue 3, pp 505-522.

[10] Fortanier, F. (2007). Foreign Direct Investment and Host Country Economic Growth: Does the Investor's Country of Origin Play a Role? Transnational Corporations, Vol. 16, No. 2.

[11] Goel, R. (2018). Foreign direct investment and entrepreneurship: gender differences across international economic freedom and taxation. Small Business Economics, Volume 50, Issue 4, pp 887-897. 
[12] Munemo, J. (2015). Foreign Direct Investment, Business Start-up Regulations, and Entrepreneurship in Africa. Economics Bulletin, 35(1).

[13] Sun, L., Lee, I. H. I., Hong, E. (2016). Does foreign direct investment stimulate new firm creation? In search of spillovers through industrial and geographical linkages. Small Business Economics, 48(3).

[14] Apostolov, M. (2017). The impact of FDI on the performance and entrepreneurship of domestic firms. Journal of International Entrepreneurship, 15(4):390-415.

[15] Albulescu, C. T., \& Tămăşilă, M. (2014). The Impact of FDI on Entrepreneurship in the European Countries. Procedia - Social and Behavioral Sciences, Volume 124, Pages 219-228. 